\title{
Behavior of Zinc in a Constructed Wetland System Receiving Domestic Wastewater
}

\author{
Kaoru ABE*, Akihito OOKUMA**, Michio KOMADA***, Sunao ITAHASHI*, Kennji \\ BANZAI* \\ * National Institute for Agro-Environmental Sciences, 3-1-3, Kannondai, Tsukuba 305-8604, \\ Japan \\ ** Koibuchi College of Agriculture and Nutrition, 5965, Koibuchimachi, Mito 319-0323, \\ Japan \\ *** National Agricultural Research Center, 3-1-1, Kannondai, Tsukuba 305-8666, Japan
}

\begin{abstract}
In Japan, environmental quality standards for $\mathrm{Zn}$ pollution were enacted recently because of the toxicity of $\mathrm{Zn}$ to aquatic ecosystems. A free-water-surface constructed wetland $\left(500 \mathrm{~m}^{2}\right)$ planted with Zizania latifolia Turcz. received secondary-treated wastewater from a dormitory (60 to 100 residents) at the Koibuchi College of Agriculture and Nutrition in Japan, to remove nutrient salts before the discharge of the water to a pond for agricultural use. We examined the removal efficiencies of $\mathrm{Zn}$ and its behavior in this constructed wetland within 3 years and discussed the mechanism of $\mathrm{Zn}$ removal. The constructed wetland was effective in treating wastewater with low $\mathrm{Zn}$ concentrations. The T-Zn concentration in secondary-treated domestic wastewater (average T-Zn: $0.048 \mathrm{mg} / \mathrm{L}$ ) decreased by $51 \%$ during passage through the constructed wetland. Most of the dissolved $\mathrm{Zn}$ was removed, but only a little particulate $\mathrm{Zn}$ was removed. The increase in $\mathrm{Zn}$ concentration in the wetland soil corresponded to $69.8 \%$ of the $\mathrm{Zn}$ removed by the wetland. However, the amount of $\mathrm{Zn}$ accumulated in the aboveground parts of $Z$. latifolia corresponded to only $9.8 \%$ of the $\mathrm{Zn}$ removed by the wetland. Thus, $\mathrm{Zn}$ was removed mainly by adsorption onto the wetland soil, including soil particles and organic matter.
\end{abstract}

Keywords: constructed wetland, domestic wastewater, secondary-treated, soil, Zizania latifolia, $\mathrm{Zn}$

\section{INTRODUCTION}

Environmental quality standards for zinc $(\mathrm{Zn})$ pollution were recently enacted in Japan because of the toxicity of $\mathrm{Zn}$ to aquatic ecosystems. These standards have been set at $0.03 \mathrm{mg} / \mathrm{L}$ for $\mathrm{Zn}$ in rivers and lakes and $2 \mathrm{mg} / \mathrm{L}$ in wastewater. $\mathrm{Zn}$ is used in various human activities, and the sources of $\mathrm{Zn}$ loading in the aquatic environment are quite varied. Zinc is an essential micronutrient for mammals, and many foods contain it. Some commodities such as shampoos and cosmetics also contain Zn. Nakanishi et al. (2008) estimated that, in Japan, $468 \mathrm{t} / \mathrm{year}$ of $\mathrm{Zn}$ is loaded from domestic wastewater to the aquatic environment and $1172 \mathrm{t} /$ year is loaded from domestic wastewater to sewage treatment systems. The $\mathrm{Zn}$ load from factories to the aquatic environment was estimated to be $700 \mathrm{t} /$ year. Domestic wastewater is therefore a major source of $\mathrm{Zn}$ pollution of aquatic ecosystems.

In recent years, considerable attention has been directed toward constructed wetlands, because of their low cost and ease of operation (Brix, 1993; Cooper, 2007; Vymazal, 2007). Most studies of heavy metal treatment in constructed wetland systems have examined heavily contaminated wastewater from mine drainage and industries

Address correspondence to Kaoru Abe, Soil Environment Division, National Institute for

Agro-Environmental Sciences, Email: abekaoru@affrc.go.jp

Received June 17, 2010, Accepted July 14, 2010. 
(Gillespie et al., 2000; Mays and Edwards, 2001). There have been few studies on the removal of heavy metals from wastewaters containing low concentrations of these metals, such as domestic wastewater, by constructed wetland systems.

Wastewater from a dormitory at the Koibuchi College of Agriculture and Nutrition (KCAN) in Ibaraki Prefecture, Central Japan, is first treated by a combined household wastewater treatment facility that uses primary and secondary treatment processes. The secondary-treated effluent is then polished by a free-water-surface-flow constructed wetland to remove nutrient salts before the effluent is discharged to a pond for agricultural use. In the previous study, we have already reported the year-round $\mathrm{N}, \mathrm{P}$, and $\mathrm{Zn}$ removal efficiencies of the constructed wetland system (Abe et al., 2008). Here, we examined $\mathrm{Zn}$ removal efficiencies and $\mathrm{Zn}$ behavior in the constructed wetland within 3 years and discussed the mechanism of $\mathrm{Zn}$ removal.

\section{MATERIALS AND METHODS}

\section{Free-water-surface-flow Constructed Wetland}

The constructed wetland is $16 \mathrm{~m}$ wide and $30 \mathrm{~m}$ long, with a water depth of $0.1 \mathrm{~m}$ (Fig. 1). It was built on a fallow paddy field at KCAN in 2004. The wetland soil is a humic gleyed andosol. A barrier of plastic boards has been installed around the wetland to prevent percolation of water. Flow-correction boards are installed every $7.5 \mathrm{~m}$ inside the wetland to prevent shortcut flow. Although Phragmites australis (reed) is commonly used in constructed wetlands, this species rapidly extends strong rhizomes that could puncture the bunds of the paddy field adjacent to the wetland. Therefore, this wetland has been planted with Zizania latifolia Turcz. (Manchurian wild rice), which, unlike reeds, causes little damage to the paddy field and has a high biomass production rate. The wetland receives about 10,000 to $30,000 \mathrm{~L} /$ day of secondary-treated wastewater from 60 to 100 dormitory residents. The average water retention time in the wetland is 2.6 days.

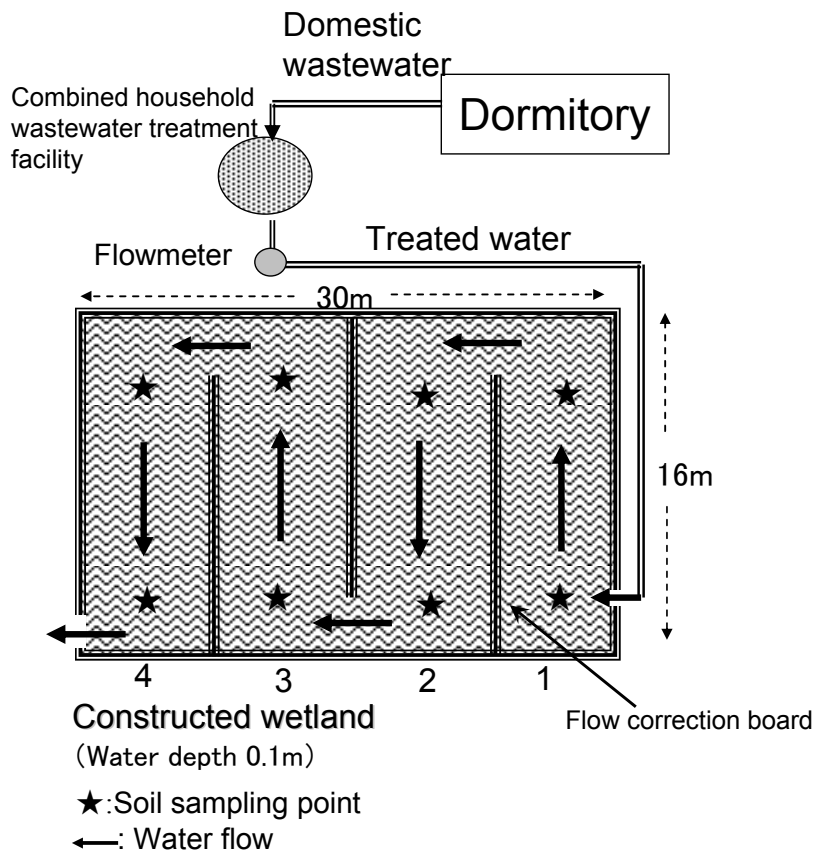

Fig. 1 - Free-water-surface-flow constructed wetland system. 


\section{Measurements}

The volume of wastewater inflow was measured with an integration flow meter. The effluent water volume was calculated as the sum of inflow and rainfall minus evapotranspiration. Because the paddy field had a hardpan (impermeable layer) under the plow layer (i.e., the topsoil) and the groundwater level was high in the biotope area, water leaching was considered to be negligible. For convenience, the typical rate of evapotranspiration from a Japanese paddy field (4.0-6.5 mm/d) (Kaneko, 1973) was used to represent that of the constructed wetland except for any rainy days $(0 \mathrm{~mm} / \mathrm{d}$ for rainy days).

Influents and effluents were collected weekly from May 2006 through October 2009 (inflow was stopped after this time) and the acid-soluble $\mathrm{Zn}$ concentration was measured. Total zinc (T-Zn) and dissolved $\mathrm{Zn}$ concentrations were measured once or twice a month. To measure the acid-soluble $\mathrm{Zn}$ concentration, water samples were adjusted to $\mathrm{pH} 1$ with nitric acid $\left(\mathrm{HNO}_{3}\right)$ just after sampling. To measure the dissolved $\mathrm{Zn}$ concentration, water samples were filtered with a $0.2 \mu \mathrm{m}$ membrane filter just after sampling. To measure the T-Zn concentration, water samples $(25 \mathrm{~mL})$ were digested with concentrated $\mathrm{HNO}_{3}(2 \mathrm{~mL})$ in Teflon beakers on a hot plate at $200-250{ }^{\circ} \mathrm{C}$.

Aboveground parts of $Z$. latifolia growing over an area of $1 \mathrm{~m}^{2}$ were harvested from four to eight sampling points in the constructed wetland every year. Samples were dried at $80^{\circ} \mathrm{C}$ for 3 days. Soil core samples at $10 \mathrm{~cm}$ depth were taken from eight sampling points (illustrated in Fig. 1) in the constructed wetland in November 2006 and January 2010, after several weeks of drainage. They were then air-dried and passed through a $2-\mathrm{mm}$ mesh sieve. The Z. latifolia $(0.2 \mathrm{~g})$ or finely ground soil $(0.2 \mathrm{~g})$ was digested with concentrated $\mathrm{HNO}_{3}(2 \mathrm{~mL})$, followed by hydrogen fluoride (HF) $(5 \mathrm{~mL})$ and perchloric acid $\left(\mathrm{HClO}_{4}\right)(1 \mathrm{~mL})$ in Teflon beakers on a hot plate at $200-250{ }^{\circ} \mathrm{C}$. To quantify the soluble $\mathrm{Zn}$, the air-dried and sieved soil was shaken with $0.1 \mathrm{~mol} / \mathrm{L} \mathrm{HCl}$ solution at a 1:5 soil to solution ratio for $1 \mathrm{~h}$ at $200 \mathrm{rpm}$ (Japanese Society of Soil Science and Plant Nutrition, 1995).

The $\mathrm{Zn}$ concentration in the solutions prepared as described above were measured with an inductively coupled plasma optical emission spectrometer (Vista-Pro, Varian Inc., Palo Alto, CA, USA) or inductively coupled plasma mass spectrometer (Agilent $7500 \mathrm{cs}$, Agilent Technologies, Santa Clara, CA, USA)

\section{RESULTS AND DISCUSSION}

The relationship between the acid-soluble $\mathrm{Zn}$ concentration and T-Zn concentration in the influents (secondary-treated domestic wastewater) and effluents is shown in Fig. 2. The acid-soluble $\mathrm{Zn}$ concentration was almost the same as the $\mathrm{T}-\mathrm{Zn}$ concentration. The slope of the linear regression between $\mathrm{T}-\mathrm{Zn}$ and acid-soluble $\mathrm{Zn}$ concentrations in the influents was 0.962 , which is quite close to $1\left(r^{2}=0.980\right)$. That of the effluents, however, was $0.875\left(r^{2}=0.910\right)$, which is a little lower. It was considered that the wetland soil which contained $\mathrm{Zn}$ flowed out with water. The T-Zn concentrations in the influents and effluents within 3 years were calculated from the acid-soluble $\mathrm{Zn}$ concentrations by using each regression equation. 
Fig. 3 illustrates the concentrations of $\mathrm{T}-\mathrm{Zn}$ in the influent and effluent of the constructed wetland. The average $\mathrm{T}-\mathrm{Zn}$ in the influent was $0.048 \mathrm{mg} / \mathrm{L}$ while the average T-Zn concentration in the effluent was $0.023 \mathrm{mg} / \mathrm{L}$ implying a $51 \%$ decrease. Our findings indicated that the constructed wetland was useful for treating wastewater with a low $\mathrm{Zn}$ concentration; the system decreased the $\mathrm{Zn}$ concentration to a level below the limit required by the Japanese water quality standard $(0.03 \mathrm{mg} / \mathrm{L})$ and this level is unlikely to have negative effects on aquatic organisms downstream.
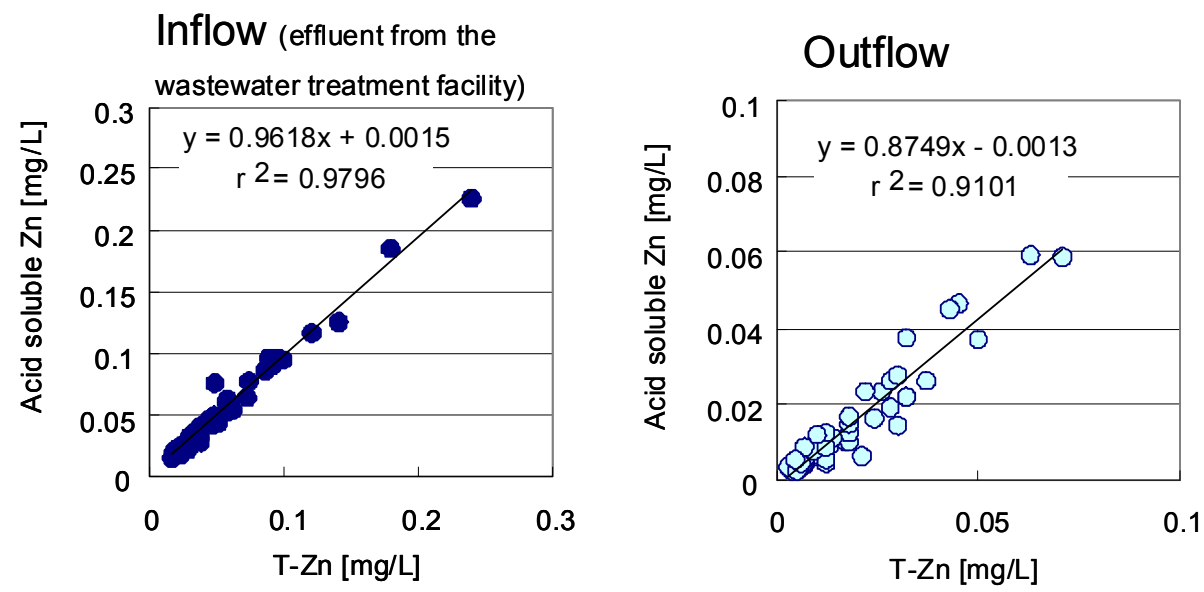

Fig. 2 - Relationship between T-Zn concentration and acid-soluble Zn concentration in the influent and effluent of the constructed wetland.

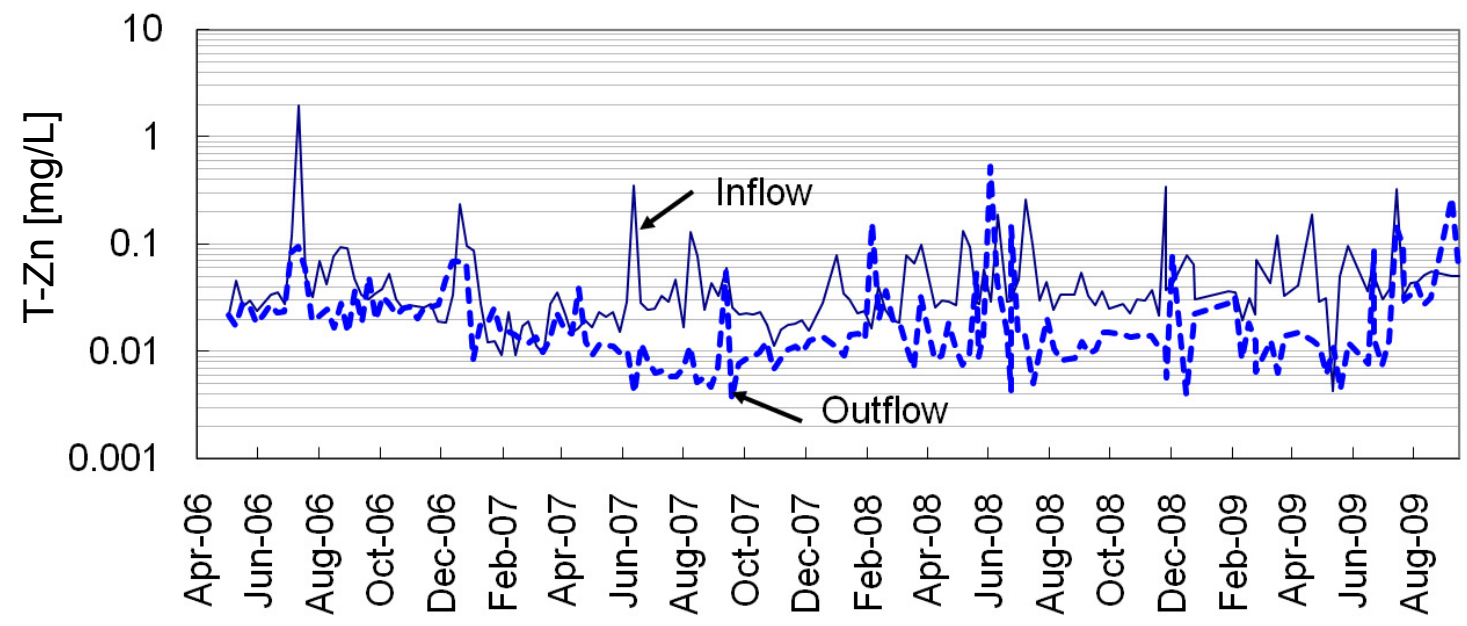

Fig. 3 - Changes in T-Zn concentration in the influent and effluent of the constructed wetland.

Fig. 4 illustrates the fractionation of $\mathrm{Zn}$ in the influent and effluent. More than $80 \%$ of the $\mathrm{Zn}$ in the influent was in the dissolved form. This result is in agreement with that of Isozaki et al. (2006), who reported that about $90 \%$ of $\mathrm{Zn}$ in treated sewage water is in the dissolved form. About $90 \%$ of the dissolved $\mathrm{Zn}$ was removed by the constructed wetland system. The particulate $\mathrm{Zn}$ ( $\mathrm{T}-\mathrm{Zn}$ minus dissolved $\mathrm{Zn}$ ) concentration hardly decreased but rather increased while the effluent was passing through the wetland, because soil in the wetland flowed out with the water. 
Fig. 5 illustrates the fractionation of $\mathrm{Zn}$ in soils in the constructed wetland. The T-Zn concentration in the wetland soil in 2010 was higher than that in 2006. An increase in soluble $\mathrm{Zn}(0.1 \mathrm{~mol} / \mathrm{L} \mathrm{HCl}$ extractable form) concentration was the main reason for this $\mathrm{T}-\mathrm{Zn}$ increase.

The $\mathrm{Zn}$ balance of the wetland within 3 years (from November 2006 to October 2009) is shown in Table 1. The $\mathrm{Zn}$ loading from the secondary effluent was $1.811 \mathrm{~g} / \mathrm{m}^{2}$ $\left(1.65 \times 10^{-3} \mathrm{~g} / \mathrm{m}^{2} /\right.$ day $)$. The amount of $\mathrm{Zn}$ removed was $0.870 \mathrm{~g} / \mathrm{m}^{2}\left(7.95 \times 10^{-4} \mathrm{~g} / \mathrm{m}^{2} /\right.$ day $)$, and the percentage removal rate was $48.0 \%$. Atmospheric deposition was one of the $\mathrm{Zn}$ sources for the aquatic environment. Zinc loading from atmospheric deposition in Japan was estimated to be $6.3 \times 10^{-5} \mathrm{~g} / \mathrm{m}^{2} /$ day (Nakanishi et al., 2008). As this value corresponded to only $3.7 \%$ of $\mathrm{Zn}$ loading from the secondary effluent in this constructed wetland, it was considered to be negligible for discussing $\mathrm{Zn}$ removal efficiency and its mechanisms in this constructed wetland. The increase in the amount of $\mathrm{Zn}$ in the top 10 $\mathrm{cm}$ of wetland soil corresponded to $69.8 \%$ of the $\mathrm{Zn}$ removed by the constructed wetland system. Eighty percent of the $\mathrm{Zn}$ increase in the soil was due to the increase in the soluble $(0.1 \mathrm{~mol} / \mathrm{L} \mathrm{HCl}$ extractable $)$ form. The amount of $\mathrm{Zn}$ accumulated in the aboveground parts of $Z$. latifolia corresponded to only $9.8 \%$ of the $\mathrm{Zn}$ removed by the constructed wetland system. Zinc removal by other pathways was considered to include $\mathrm{Zn}$ accumulation in the roots of $Z$. latifolia and the biomass of other species.

These results indicated that the $\mathrm{Zn}$ in the secondary-treated domestic wastewater was removed mainly by adsorption onto the wetland soil. One of the mechanisms for $\mathrm{Zn}$ removal was considered to be adsorption of $\mathrm{Zn}^{2+}$ onto the minus charge of clay minerals and organic matter (like humic substances) in wetland soil. Humic gleyed andosol is rich in humic substances, therefore we think that the wetland soil adsorbed $\mathrm{Zn}^{2+}$ effectively. Isozaki et al. (2006) reported that the fraction of free ion in dissolved $\mathrm{Zn}$ in effluents from the sewage treatment plants was $12-47 \%$. They also suggested that residual fraction in dissolved $\mathrm{Zn}$ was $\mathrm{Zn}-\mathrm{DOM}$ (zinc and dissolved organic matter) complex. Further studies on the reaction of dissolved $\mathrm{Zn}$ with wetland soil are needed.
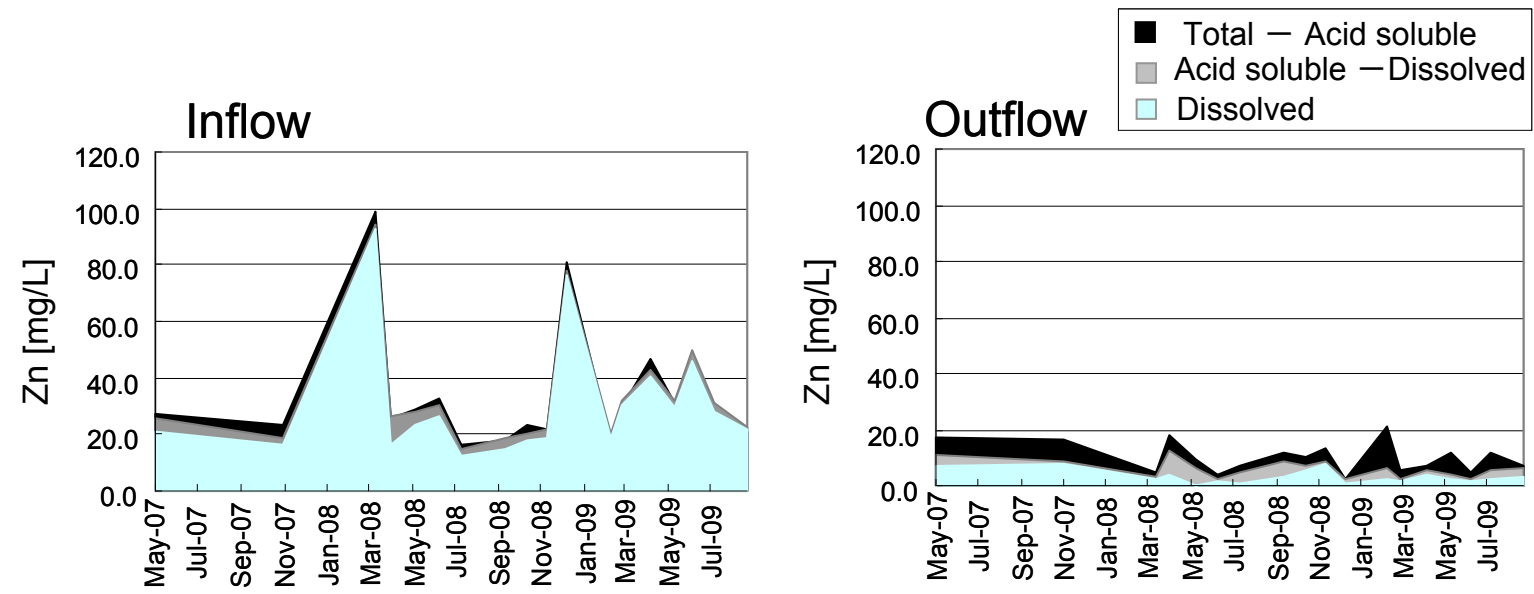

Fig. 4 - Fractionation of $\mathrm{Zn}$ in the influent and effluent of the constructed wetland. (The concentration of $\mathrm{Zn}$ was measured once a month.) 

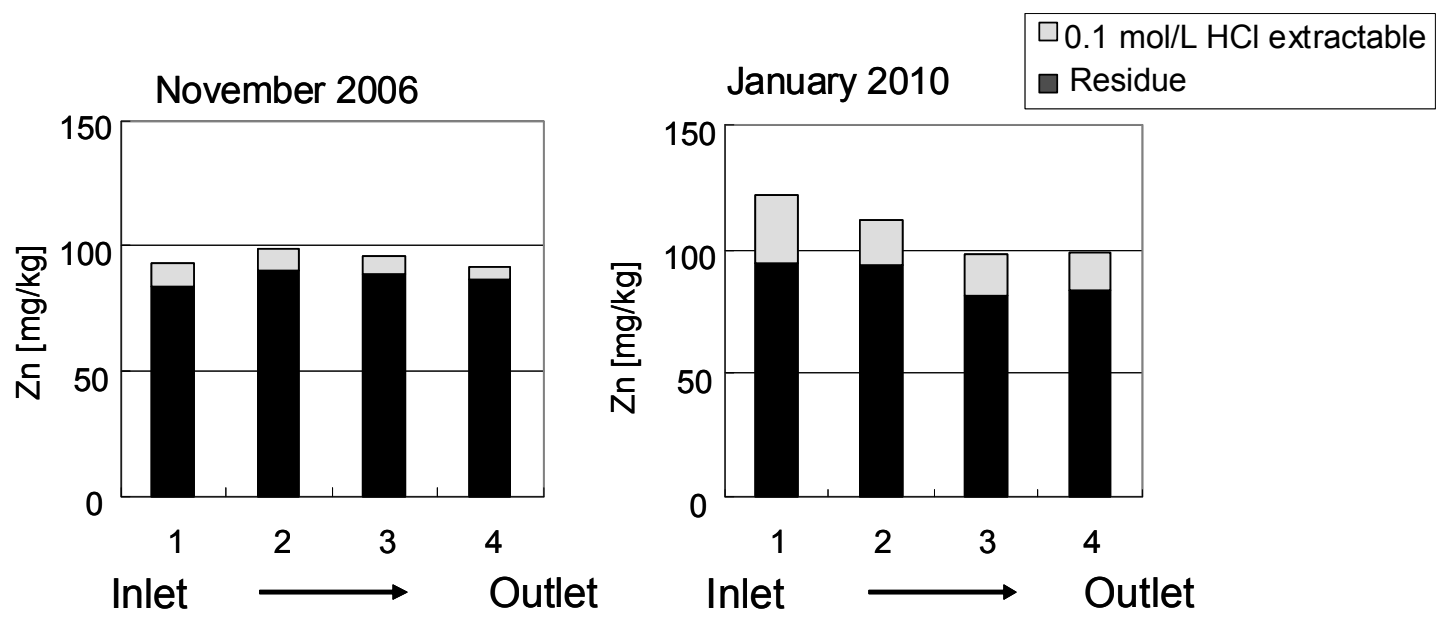

Fig. 5 - Fractionation of Zn in wetland soil in November 2006 and January 2010.

(The average $\mathrm{Zn}$ concentrations of soil samples were taken from each block in the wetland, and the soil sampling points and block numbers are illustrated in Fig. 1.)

Table 1 - Zinc balance from November 2006 to October 2009 in free-water-surface constructed wetland planted with Z. latifolia

\begin{tabular}{cccccccc}
\hline & Inflow & \multicolumn{4}{c}{ Removal } & \multicolumn{3}{c}{ Outflow } \\
\cline { 2 - 7 } & & $\begin{array}{c}\text { Accumulation in } \\
\text { soil (top 10cm) }\end{array}$ & $\begin{array}{c}\text { (Soluble } \\
\text { form) }\end{array}$ & $\begin{array}{c}\text { Plant } \\
\text { uptake }\end{array}$ & $\begin{array}{c}\text { Removal for } \\
\text { other reason }\end{array}$ & $\begin{array}{c}\text { Total } \\
\text { removal }\end{array}$ & \\
\hline $\mathrm{Zn}\left[\mathrm{g} / \mathrm{m}^{2}\right]$ & 1.811 & 0.607 & $(0.571)$ & 0.086 & 0.224 & 0.870 & 0.941 \\
\hline $\begin{array}{c}\% \text { to } \\
\text { inflow }\end{array}$ & 100 & 33.5 & $(31.5)$ & 4.7 & 9.8 & 48.0 & 52.0 \\
\hline $\begin{array}{c}\text { \% to total } \\
\text { removal }\end{array}$ & - & 69.8 & $(65.6)$ & 9.8 & 20.4 & 100 & - \\
\hline
\end{tabular}

\section{CONCLUSIONS}

(1) The constructed wetland was useful for treating wastewater with a low $\mathrm{Zn}$ concentration; the system decreased the $\mathrm{Zn}$ concentration to a level below the water quality standard.

(2) Most of the dissolved $\mathrm{Zn}$ was removed by the constructed wetland system, but little particulate $\mathrm{Zn}$ was removed.

(3) The increase in $\mathrm{Zn}$ concentration in the wetland soil corresponded to $69.8 \%$ of the $\mathrm{Zn}$ removed by the wetland system. The $\mathrm{Zn}$ increase in the wetland soil was mainly due to an increase in the soluble $(0.1 \mathrm{~mol} / \mathrm{L} \mathrm{HCl}$ extractable $)$ form. The amount of $\mathrm{Zn}$ accumulated in the aboveground parts of $Z$. latifolia corresponded to only $9.8 \%$ of the $\mathrm{Zn}$ removed by the wetland.

(4) Our results indicated that $\mathrm{Zn}$ was removed mainly by adsorption onto both soil particles and organic matter of the wetland soil.

\section{REFERENCES}

Abe K., Komada M. and Ookuma A. (2008). Efficiency of removal of nitrogen, phosphorus and zinc from domestic wastewater by a constructed wetland system in rural areas: a case study, Wat. Sci. Technol., 58, (12), 2427-2433.

Brix H. (1993). Wastewater treatment in constructed wetland: system design, removal 
process, and treatment performance. In: Constructed Wetlands for Water Quality Improvement, G. A. Moshiri (ed.), CRC Press Inc., Boca Raton, FL, pp. 9-22.

Cooper P. (2007). The constructed wetland association UK database of constructed wetland systems, Water Science and Technology, 56(3), 1-6.

Gillespie W. B., Hawkins W. B., Rodgers J. H. Jr., Cano M. L. and Dorn P. B. (2000). Transfers and transformations of zinc in constructed wetlands: mitigation of a refinery effluent, Ecological Engineering, 14, 279-292.

Isozaki Y., Nakajima F. and Furumai H. (2006). Speciation of zinc, copper and nickel in domestic wastewater treatment process and in receiving river water, Environmental Science, 19(5), 445-452 (in Japanese with English summary).

Japanese Society of Soil Science and Plant Nutrition (ed.) (1995). Methods for the Analysis of Soil Environments (Dojyou Kannkyou Bunnseki Hou). Hakuyuu-sha, Tokyo, Japan (in Japanese).

Kaneko R. (1973). Hydrology Course 12; Agricultural Hydrology, Kyoritsu Shuppan Co., Ltd, Tokyo (in Japanese).

Mays P. A. and Edwards G. S. (2001). Comparison of heavy metal accumulation in a natural wetland and constructed wetlands receiving acid mine drainage, Ecological Engineering, 16, 487-500.

Nakanishi J., Naito W. and Kamo M. (2008). Risk Assessment Document Series 20: Zinc, Maruzen, Tokyo, Japan (in Japanese).

Vymazal J. (2007). Removal of nutrients in various types of constructed wetlands, Science of the Total Environment, 380, 48-65. 